\title{
Fewer complications result from a video-assisted approach to anatomic resection of clinical stage I lung cancer
}

\author{
Daniel J. Boffa, MD, ${ }^{a}$ Anish Dhamija, BS, ${ }^{a}$ Andrzej S. Kosinski, PhD, ${ }^{b}$ Anthony W. Kim, MD, ${ }^{a}$ \\ Frank C. Detterbeck, MD, ${ }^{\mathrm{a}}$ John D. Mitchell, MD, ${ }^{\mathrm{c}}$ Mark W. Onaitis, MD, ${ }^{\mathrm{d}}$ and Subroto Paul, MD
}

\begin{abstract}
Objectives: Anatomic resection is currently the standard of care for clinical stage I lung cancer, yet clinicians increasingly pursue nonsurgical, ablative therapies to avoid the morbidity of thoracotomy. The video-assisted thoracic surgery (VATS) approach is a minimally invasive alternative to thoracotomy yet the effect of VATS on the morbidity of patients undergoing lung cancer resection is not fully characterized. We evaluated complications following anatomic resection of clinical stage I lung cancer by VATS and thoracotomy to clarify the effect of the minimally invasive approach.
\end{abstract}

Methods: The Society of Thoracic Surgeons database was queried for lobectomies and segmentectomies performed between 2001 and 2010 for clinical stage I primary cancer.

Results: A total of 11,531 (7137 open and 4394 VATS) patients with clinical stage I primary lung cancers underwent resection. Propensity scoring was used to match cases into 2745 well-balanced pairs. Overall complications were significantly more likely in the thoracotomy group $(36 \%)$ than in the VATS cohort $(30 \%$; $P<.001)$. Patients undergoing thoracotomy experienced significantly more pulmonary complications $(21 \%$ vs $18 \%$ ), atrial arrhythmias ( $13 \%$ vs $10 \%)$, and were more likely to undergo transfusion $(6 \%$ vs $4 \%)$. Operative mortality was similar (thoracotomy $1.8 \%$, VATS $1.3 \% ; P=.13$ ).

Conclusions: Anatomic resection of early stage lung cancer is performed with a low mortality rate, according to data from the Society of Thoracic Surgeons database. Perioperative complications are significantly less likely to occur when patients with stage I lung cancers undergo resection using the VATS approach. Further study is warranted to determine long-term effects of these differences in perioperative outcomes. (J Thorac Cardiovasc Surg 2014; 148:637-43)

Earn CME credits at

http://jtcvs.com/cme/home

Stage I lung tumors are likely to become most common presentation of primary lung cancer as a result of progressive adoption of screening with computed tomography scanning. Results from the landmark National Lung Screening trial suggest the prevalence of stage I non-small cell lung cancer (NSCLC) at presentation will increase from $20 \%$ to $25 \%$ of patients with NSCLC to $>60 \%$. ${ }^{1}$

\footnotetext{
From the Department of Thoracic Surgery, ${ }^{\text {a }}$ Yale University School of Medicine, New Haven, Conn; Departments of Biostatistics and Bioinformatics and Thoracic Surgery, ${ }^{\mathrm{b}}$ Duke University, Durham, NC; Division of Cardiothoracic Surgery, ${ }^{\mathrm{c}}$ University of Colorado Denver School of Medicine, Aurora, Colo; Department of Thoracic Surgery, ${ }^{\mathrm{d}}$ Duke University Medical Center, Durham, NC; and Department General Thoracic Surgery, ${ }^{\mathrm{e}}$ New York-Presbyterian/Weill Cornell Medical Center, New York, NY.

Disclosures: Authors have nothing to disclose with regard to commercial support.

Received for publication April 2, 2013; revisions received Nov 13, 2013; accepted for publication Dec 26, 2013; available ahead of print Feb 14, 2014.

Address for reprints: Daniel J. Boffa, MD, 330 Cedar St, BB205, PO Box 208062,

New Haven, CT 06520-8062 (E-mail: daniel.boffa@yale.edu).

$0022-5223 / \$ 36.00$

Copyright $(2014$ by The American Association for Thoracic Surgery

http://dx.doi.org/10.1016/j.jtcvs.2013.12.045
}

Therefore a comprehensive understanding of treatmentassociated morbidity in early stage lung cancer is critical.

Anatomic pulmonary resection is currently the standard of care for the treatment of clinical stage I lung cancer, ${ }^{2}$ yet concerns over the morbidity associated with a traditional thoracotomy have motivated patients and clinicians to pursue less-invasive strategies for lung cancer management. Video-assisted thoracic surgery (VATS) is a minimally invasive alternative to thoracotomy for anatomic lung cancer resection that is associated with less discomfort, shorter hospitalization, and a faster recovery. ${ }^{3,4}$ However, the effect of surgical approach on complication rates in clinical stage I cancer has been incompletely addressed. Therefore, we examined complication rates following anatomic resection in patients with clinical stage I NSCLC via VATS and thoracotomy by Board-certified thoracic surgeons to determine the result of approach on operative morbidity.

\section{METHODS}

The Society of Thoracic Surgeons General Thoracic Database (STS-GTD) was queried for surgically managed primary lung cancer. Eligible patients included those undergoing anatomic pulmonary resections for treatment naive, clinical stage T1 N0 M0 and T2 N0 M0 primary lung cancer in the STS-GTD between 2001 and 2010. During 2009, the stage classification system was modified from the sixth edition of the American Joint Committee on Cancer staging manual ( $56 \%$ of our study population), to the seventh edition $(44 \%)$. Of the 24,626 primary lung cancer patients in the STS-GTD, 18,928 


\section{Abbreviations and Acronyms \\ NSCLC = non-small cell lung cancer \\ STS-GTD $=$ Society of Thoracic Surgeons General \\ Thoracic Database \\ VATS $=$ video-assisted thoracic surgery}

(77\%) contained sufficiently complete clinical staging information to be considered. This figure improved over the course of the study, with $93 \%$ of cases containing complete clinical staging information in 2009 and 2010. We excluded patients with missing data for the pathologic $\mathrm{N}$ variable, or who were pathologically staged to be $\mathrm{N} 3$ ( 8 patients). The study population contained insufficient numbers of minimally invasive pneumonectomies (VATS $=17$ patients), bilobectomies (VATS $=70$ ), and sleeve lobectomies $($ VATS $=10)$ for meaningful comparison and were therefore excluded from both cohorts. The current version of the database does not distinguish VATS segmentectomies from VATS lobectomies and therefore lobectomies and segmentectomies were analyzed as a combined group for both thoracotomy and VATS cohorts for the entire study period. The rates of segmentectomy in the previous version of the database that did distinguish VATS lobectomy from segmentectomy (STS-GTD 2.07) were similar (thoracotomy $6.5 \%$ and VATS $8 \%$ ). Between 2001 and 2010, a total of 11,531 lobectomies or segmentectomies (7137 via thoracotomy and 4394 VATS) for clinical stage I primary lung cancer were recorded in the STS-GTD.

The STS-GTD is a voluntary database, but participants are bound by contract to submit complete unselected cases and are provided with yearly reports concerning missing or outlier data. The STS-GTD has been subjected to external audit annually, beginning in 2010. Approximately $5 \%$ of the data were audited and the overall accuracy was $93 \%$.

\section{Conversions}

There is not a field in the STS-GTD to indicate a conversion from VATS to thoracotomy. However in version 2.07 of the STS-GTD data form an approach field exists that allows abstractors to select $>1$ approach. Cases of lobectomy or segmentectomy coded with both thoracoscopy and thoracotomy as the surgical approach were considered combined procedures (potentially representing conversions). Version 2.081 allowed primary procedures as well as secondary procedures to be captured. Primary procedures coded as lobectomy or segmentectomy by thoracotomy, with a secondary VATS procedure on the same day were considered to have had a combined approach (potentially representing a conversion).

\section{Statistics}

The Duke Clinical Research Institute supervised all statistical analysis. Comparisons of patient characteristics between groups were made using the 2-sample nonparametric Wilcoxon test for continuous variables and the $\chi^{2}$ test for categorical variables. Multivariable analysis utilized logistic regression. $P$ values were not adjusted for multiplicity.

Annual study case volume of lobectomy or segmentectomy for clinical stage I primary lung cancer $(\mathrm{N}=11,531)$ was estimated for each of the providers. Surgeons were identified by their national provider identifier number (years 2009-2010) or surgeon name, national provider identifier when available, and participant number. Out of 11,531 study cases, surgeon information was missing for 350 operations $(3 \%)$. Yearly study case volume of lobectomy or segmentectomy for clinical stage I primary lung cancer was averaged during the surgeon's activity period (or if the activity period was shorter than 6 months, estimated over the interval between case submission and data harvest date for the year in question, with 2 months as a minimum activity period). For incorporation into a multivariable analysis, the surgeons were divided into quartiles with the following annual volume distributions: $\geq 0.7$ and $<10, \geq 10$ and $<17, \geq 17$ and $<27$, and $\geq 27$ and $\leq 70.2$.
A multivariable analysis was performed using patients with complete information $(\mathrm{n}=8310)$ for 23 variables (use of mediastinal staging procedure, clinical T stage, age, gender, race, body mass index, predicted forced expiratory volume in 1 second, predicted diffusing capacity of carbon monoxide, year of surgery, clinical status at time of surgery, general thoracic reoperation, prior thoracic surgery, laterality, American Society of Anesthesiologists risk class, smoking status, Zubrod score, weight loss in 3 months before admission, hypertension, use of steroids, congestive heart failure, coronary artery disease, peripheral vascular disease, and renal insufficiency). A full list of data fields in the STS-GTD can be found at http://www.sts.org/quality-research-patient-safety/national-database/data base-managers/general-thoracic-surgery-databa-1.

In an attempt to eliminate potentially confounding differences in the patient populations within the 2 cohorts, a propensity-matched analysis was performed as described in our previous publication using this dataset. ${ }^{5} \mathrm{~A}$ patient's propensity for having undergone a VATS procedure was determined by a logistic regression model using 23 preoperative patient characteristics as independent variables (see above multivariable description). The estimated probability of having undergone a VATS procedure was determined as a propensity score and used to match pairs of patients undergoing VATS and thoracotomy using a Greedy 5 to 1 digit algorithm, ${ }^{6}$ similar to the propensity strategy used in previous report from the STS-GTD. ${ }^{3}$ The majority of pairs had differences in propensity score $<0.0001$ and matched pairs were not formed if propensity score difference exceeded 0.1 . The missing data for complications averaged $0.7 \%$ for the variables. There was no difference in the frequency of missing data for the complications by approach in the open and VATS cohorts, with the exception of discharge with chest tube, in which the data was missing in $1.1 \%$ of open and $.5 \%$ of VATS patients $(P<.001)$. The database analysis interprets a failure to indicate the presence of a complication as the absence of that particular complication.

\section{RESULTS Patients}

The patient and tumor attributes of the thoracotomy and VATS groups are listed in Table 1. Several important differences were identified, including a greater frequency of T1 tumors in the VATS cohort $(76 \%$ vs $65 \% ; P<.001)$ and better pulmonary function in VATS cohort (ie, predicted forced expiratory volume in 1 second of $83 \%$ vs $78 \% ; P<.001$ ). The VATS procedures were performed by surgeons that averaged more lobectomies for clinical stage I primary lung cancer each year (median, 20.4 vs 15.7 procedures per year; $P<.001$ ).

\section{Multivariable Analysis of Complication Risk}

Overall, $34 \%$ of patients experienced at least 1 complication. Patients undergoing thoracotomy were more likely to experience a complication (36.4\%) than the VATS patients $(28.9 \%)(P<.001)$. A multivariable analysis was performed to identify risk factors for the development of complications, and variables associated with a significant effect on complication risk are shown in Table 2. The VATS approach was associated with a lower risk of complications than thoracotomy (odds ratio, 0.775; 95\% confidence interval, 0.702-0.856; $P<.001)$. Increasing annual surgeon volume of lobectomy and segmentectomy for clinical stage I primary lung cancer was associated with a reduction in complication risk, with surgeons performing $>27$ per year having significantly fewer complications than surgeons performing $<10$ per year (odds ratio, $0.783 ; 95 \%$ confidence interval, $0.686-0.894 ; P<.001)$. 
TABLE 1. Patient, tumor, and procedure characteristics

\begin{tabular}{|c|c|c|c|}
\hline & $\begin{array}{c}\text { Thoracotomy } \\
(n=7137)\end{array}$ & $\begin{array}{c}\text { Video-assisted } \\
\text { thoracic } \\
\text { surgery } \\
(\mathrm{n}=\mathbf{4 3 9 4}) \\
\end{array}$ & $P$ value \\
\hline Clinical stage $(\%)$ & & & $<.001$ \\
\hline T1 & 64.6 & 76.1 & \\
\hline $\mathrm{T} 2$ & 35.4 & 23.9 & \\
\hline \multicolumn{4}{|l|}{ Extent of resection $(\mathrm{n}[\%])$} \\
\hline Lobectomy & $6667(93.4)$ & $1948(92)^{*}$ & \\
\hline Segmentectomy & $470(6.6)$ & $170(8)^{*}$ & \\
\hline $\begin{array}{l}\text { Estimated yearly surgeon } \\
\text { volume* (median } \\
\text { [interquartile range]) }\end{array}$ & $16.2(9.1-27.2)$ & $19.8(12.3-28.9)$ & $<.001$ \\
\hline Age at time of surgery $(y)$ & & & .032 \\
\hline $\begin{array}{l}\text { Mean } \pm \text { standard } \\
\text { deviation }\end{array}$ & $67.3 \pm 10.3$ & $67.9 \pm 10.2$ & \\
\hline Range & $18-96$ & $21-95$ & \\
\hline \multicolumn{4}{|l|}{ Gender $(\%)$} \\
\hline Female & 50.6 & 56.8 & $<.001$ \\
\hline Race $(\%)$ & & & $<.001$ \\
\hline White & 88.4 & 87.7 & \\
\hline Black & 8.4 & 7.6 & \\
\hline Hispanic & 1.6 & 2.0 & \\
\hline Asian & 1.6 & 2.7 & \\
\hline \multicolumn{4}{|l|}{ Body mass index $(\%)$} \\
\hline$>35$ & 10.3 & 8.3 & $<.001$ \\
\hline \multicolumn{4}{|l|}{ FEV1 $(\%$ predicted $)$} \\
\hline $\begin{array}{l}\text { Mean } \pm \text { standard } \\
\text { deviation }\end{array}$ & $78.5 \pm 22$ & $83 \pm 22.8$ & $<.001$ \\
\hline \multicolumn{4}{|l|}{ DLCO $(\%$ predicted $)$} \\
\hline $\begin{array}{l}\text { Mean } \pm \text { standard } \\
\text { deviation }\end{array}$ & $72.3 \pm 22.7$ & $75.2 \pm 22.6$ & $<.001$ \\
\hline Year of surgery $(\%)$ & & & $<.001$ \\
\hline $2001-2004$ & 12.6 & 3.1 & \\
\hline 2005 & 9.1 & 3.5 & \\
\hline 2006 & 11.2 & 8.1 & \\
\hline 2007 & 12.2 & 13.7 & \\
\hline 2008 & 15.7 & 19.8 & \\
\hline 2009 & 26.9 & 34.1 & \\
\hline 2010 & 12.3 & 17.7 & \\
\hline Clinical status $(\%)$ & & & $<.001$ \\
\hline Elective & 95.3 & 98.2 & \\
\hline Urgent & 3.5 & .7 & \\
\hline Emergent & 1.2 & 1.1 & \\
\hline $\begin{array}{l}\text { General thoracic } \\
\text { reoperation }(\%)\end{array}$ & & & $<.001$ \\
\hline Yes & 4.5 & 2.7 & \\
\hline Laterality of procedure $(\%)$ & & & .004 \\
\hline Right & 57.4 & 60.2 & \\
\hline $\begin{array}{l}\text { American Society of } \\
\text { Anesthesiologists } \\
\text { risk class (\%) }\end{array}$ & & & $<.001$ \\
\hline I-II & 18.4 & 24.2 & \\
\hline III & 69.6 & 70.2 & \\
\hline IV-IV & 12 & 5.6 & \\
\hline
\end{tabular}

TABLE 1. Continued

\begin{tabular}{|c|c|c|c|}
\hline & $\begin{array}{c}\text { Thoracotomy } \\
(\mathbf{n}=\mathbf{7 1 3 7})\end{array}$ & $\begin{array}{c}\text { Video-assisted } \\
\text { thoracic } \\
\text { surgery } \\
(n=4394)\end{array}$ & $P$ value \\
\hline Cigarette smoker $(\%)$ & & & .047 \\
\hline Ever & 85.1 & 83.7 & \\
\hline Med staging procedure $(\%) \dagger$ & & & $<.001$ \\
\hline Day of surgery or $\leq 45 \mathrm{~d}$ & 69.4 & 80.3 & \\
\hline \multicolumn{4}{|c|}{$\begin{array}{l}F E V 1 \text {, Forced expiratory volume in } 1 \text { second; } D L C O \text {, carbon monoxide diffusing ca- } \\
\text { pacity. *Estimated surgeon volume was calculated by dividing the number of study } \\
\text { cases (the } 11,531 \text { lobectomies and segmentectomies) performed by the surgeon } \\
\text { over the time frame in which the surgeon submitted cases. } \dagger \text { Med staging procedure } \\
\text { includes mediastinoscopy, anterior mediastinoscopy, mediastinal lymph node biopsy, } \\
\text { extended cervical mediastinoscopy, mediastinal lymph node dissection, mediastinal } \\
\text { lymph node sampling, thoracoscopy diagnostic mediastinal space with biopsy, endo- } \\
\text { bronchial ultrasound, and thoracic lymphadenectomy. }\end{array}$} \\
\hline
\end{tabular}

\section{Outcomes Within Propensity-Matched Cohorts}

To account for potentially confounding differences in the approach-stratified cohorts, a propensity analysis with matching was performed resulting in 2745 well-balanced matched pairs. Table 3 demonstrates that the VATS and thoracotomy cohorts were extremely well matched, with the exception of surgeon volume, which was not included in the propensity score.

The length of stay was shorter in the VATS cohort (mean, $5.6 \pm 8.4$ days for VATS vs $7.1 \pm 7.0$ days for thoracotomy; $P<.001)$. Complication rates were higher in the thoracotomy cohort $(36 \%$ vs $30 \% ; P<.001)$ (Table 4). Operative mortality was not significantly different in the 2 groups (1.8 vs $1.3 \% ; P=.13)$. Pulmonary complications were higher in the thoracotomy cohort (eg, pneumonia: $4.6 \%$ in the thoracotomy group and $3.4 \%$ in the VATS group), as were cardiovascular complications (eg, atrial fibrillation: $12.7 \%$ in thoracotomy patients and $9.7 \%$ in VATS patients) and the need for blood transfusion $(6.2 \%$ in the thoracotomy group vs $4.0 \%$ in the VATS group).

Infectious complications were similar between the 2 cohorts (thoracotomy $3.6 \%$ vs VATS $3.0 \% ; P=.17$ ). Prolonged air leak was not different between the 2 groups $(10.9 \%$ vs $10.7 \%)$ but discharge home with a chest tube was higher in the VATS cohort $(8.4 \%$ VATS vs $5.9 \%$ thoracotomy; $P<.001)$.

Readmissions were examined as a postoperative event. However readmissions within 30 days of surgery were not captured by the STS-GTD before 2009. Among propensity-matched cases, readmissions within 30 days of surgery were similar between the thoracotomy (81 out of $1386)$ and VATS (94 out of 1418) approaches (5.5\% and $6.2 \%$, respectively; $P=.42$ ). Because roughly half of the propensity-matched cases lacked this outcome variable (before 2009), we also examined readmissions in the unmatched groups. Among patients undergoing resection in 
TABLE 2. Multivariable analysis $(n=8310)$ of risk to develop any postoperative complication

\begin{tabular}{|c|c|c|c|}
\hline Characteristic & $\begin{array}{l}\text { Odds } \\
\text { ratio }\end{array}$ & $\begin{array}{c}95 \% \\
\text { Confidence } \\
\text { interval } \\
\end{array}$ & $P$ value \\
\hline Approach (VATS vs open) & 0.763 & $0.691-0.842$ & $<.001$ \\
\hline \multicolumn{4}{|l|}{ Average annual surgeon volume } \\
\hline$\geq 0.7$ and $<10^{*}$ & 1.00 & & $<.001$ \\
\hline$\geq 10$ and $<17$ & 0.967 & $0.848-1.104$ & \\
\hline$\geq 17$ and $<27$ & 0.837 & $0.7270-0.964$ & \\
\hline$\geq 27$ and $\leq 70.2$ & 0.783 & $0.686-0.894$ & \\
\hline Age at time of surgery & 1.030 & $1.025-1.035$ & $<.001$ \\
\hline \multicolumn{4}{|l|}{ Race } \\
\hline White* & 1.00 & & .002 \\
\hline Black & 0.718 & $0.599-0.860$ & \\
\hline Hispanic & 0.768 & $0.519-1.37$ & \\
\hline Asian & 0.923 & $0.640-1.332$ & \\
\hline FEV1 (\% predicted) & 0.991 & $0.989-0.994$ & $<.001$ \\
\hline Thoracic reoperation (yes vs no) & 1.656 & $1.317-2.081$ & $<.001$ \\
\hline \multicolumn{4}{|l|}{$\begin{array}{l}\text { American Society of Anesthesiologists } \\
\text { risk class }\end{array}$} \\
\hline $\mathrm{I}-\mathrm{II} *$ & 1.00 & & $<.001$ \\
\hline III & 1.319 & $1.155-1.507$ & \\
\hline IV-V & 1.641 & $1.363-1.976$ & \\
\hline Cigarette smoking (ever vs never) & 1.392 & $1.200-1.615$ & $<.001$ \\
\hline \multicolumn{4}{|l|}{ Zubrod score } \\
\hline $0-$ normal activity* & 1.000 & & \\
\hline 1 - symptoms by fully ambulatory & 1.064 & $0.964-1.173$ & .001 \\
\hline 2 - symptoms, in bed $<50 \%$ of time & 1.516 & $1.225-1.877$ & \\
\hline $\begin{array}{l}3 \text { - symptoms, in bed }>50 \% \text { but } \\
<100 \%\end{array}$ & 1.525 & $0.977-2.382$ & \\
\hline Steroids (yes vs no) & 1.489 & $1.182-1.877$ & .001 \\
\hline Peripheral vascular disease (yes vs no) & 1.215 & $1.056-1.399$ & .007 \\
\hline Renal insufficiency (yes vs no) & 1.636 & $1.264-2.118$ & $<.001$ \\
\hline
\end{tabular}

VATS, Video-assisted thoracic surgery; FEVI, forced expiratory volume in 1 second. *The risk of complications among subsequent subsets were compared with complications in the first subset.

2009 or later, readmissions within 30 days were similar between the thoracotomy (167 out of 2607) and VATS (149 out of 2156$)$ cohorts $(6.4 \%$ and $6.9 \%$, respectively; $P=.52)$.

\section{Evaluation of Conversion Effect}

It is possible that particularly complex VATS cases or those with intraoperative complications were converted to thoracotomy, thereby biasing outcome results against thoracotomy procedures. The STS-GTD does not contain a field to represent conversion per se; however, in both versions of the database there were indicators to determine if VATS and open procedures were performed on the same day (see the Methods section). A total of 1292 patients were coded as having a VATS approach procedure in addition to thoracotomy for lobectomy or segmentectomy (representing 18.1\% of the thoracotomy cohort).

The more recent version of the database form (version 2.081) differentiates the secondary VATS procedures, which included most commonly diagnostic thoracoscopy of lungs and pleura $(57 \%)$, therapeutic wedge resection $(22 \%)$, and thoracoscopy of mediastinal space $(2 \%)$.

The use of both VATS and thoracotomy was not associated with a higher complication rate compared with thoracotomy alone $(38.5 \%$ vs $35.9 \% ; P=.071)$. However, the VATS cohort remained less likely to experience a complication, even when the combined approach cases (potentially containing converted cases) were excluded from the thoracotomy cohort $(28.9 \%$ vs $35.9 \% ; P<.001)$.

\section{DISCUSSION}

Overall, postoperative complications were reported in $34 \%$ of patients after lobectomy or segmentectomy for clinical stage I lung cancer in the STS-GTD. The database reflects the experience of Board-certified thoracic surgeons and the complication rates compare favorably to databases with more heterogeneous surgical representation. For example the Health Care Utilization Project reported a complication rate for lobectomy of $43 \%$, whereas the Surveillance, Epidemiology, and End Results Medicare database reported a complication rate of $56 \%$ (Table 5). Similarly the operative mortality for early stage lung cancer in the STS-GTD (1.4\%) appears considerably lower than databases containing surgeons with more diverse backgrounds (the Health Care Utilization Project 3.2\% and Surveillance, Epidemiology, and End Results 3.6\%). ${ }^{7,8}$

The VATS approach to anatomic lung cancer resection was associated with significantly fewer complications than thoracotomy in STS-GTD, a finding that echoes reports from the National Surgical Quality Improvement Program, ${ }^{9}$ the Healthcare Utilization Project, ${ }^{10}$ as well as earlier studies from the STS-GTD $^{3,11}$ (Table 5). Our study represents the largest study to date to evaluate treatment-associated morbidity in surgically managed, clinical stage I primary lung cancer.

The comprehensive classification of complications by the STS-GTD database has allowed the VATS effect on surgical morbidity to be more fully characterized. A reduction in pulmonary complications in the VATS cohort is perhaps the most intuitive, because of the reduction in chest wall and lung manipulation and postoperative pain. The finding that air leak prevalence was similar between VATS and thoracotomy cohorts (or perhaps even worse, because more VATS patients were discharged with a chest tube potentially representing an air leak) is a bit surprising. The proponents of VATS typically advocate a fissureless technique (thereby avoiding instrumentation of the fissure, a maneuver suspected of generating air leaks). ${ }^{12}$ Possible explanations could be variable adherence to fissureless principles by VATS surgeons adopting the technique, or alternatively the use of the fissureless technique by surgeons performing lung cancer resections via thoracotomy. Finally, this could reflect a difference in surgeon comfort with patients being discharged with chest tubes.

Our study identified a significantly lower incidence of postoperative atrial fibrillation ( $25 \%$ fewer cases) when 
TABLE 3. Patient, tumor, and procedure characteristics in propensity-matched cohorts

\begin{tabular}{|c|c|c|c|}
\hline & $\begin{array}{c}\text { Thoracotomy } \\
(n=2745)\end{array}$ & $\begin{array}{c}\text { Video-assisted } \\
\text { thoracic } \\
\text { surgery } \\
(n=2745)\end{array}$ & $\begin{array}{c}P \\
\text { value }\end{array}$ \\
\hline Clinical stage $(\%)$ & & & .67 \\
\hline $\mathrm{T} 1$ & 74.0 & 73.4 & \\
\hline $\mathrm{T} 2$ & 26.0 & 26.6 & \\
\hline Age at time of surgery $(y)$ & & & .94 \\
\hline Mean \pm standard deviation & $68.1 \pm 9.9$ & $68.2 \pm 10$ & \\
\hline $\begin{array}{l}\text { Estimated yearly surgeon } \\
\text { volume* (median } \\
\text { [interquartile range]) }\end{array}$ & $15.7(9-26.6)$ & $20.4(12.5-29.2)$ & $<.001$ \\
\hline Gender $(\%)$ & & & .98 \\
\hline Female & 54.2 & 54.2 & \\
\hline Race $(\%)$ & & & .90 \\
\hline White & 88.9 & 89.3 & \\
\hline Black & 7.5 & 7.5 & \\
\hline Hispanic & 1.6 & 1.5 & \\
\hline Asian & 2.0 & 1.7 & \\
\hline Body mass index $(\%)$ & & & .85 \\
\hline$\leq 35$ & 90.3 & 90.4 & \\
\hline$>35$ & 9.7 & 9.6 & \\
\hline FEV1 (\% predicted) & & & .73 \\
\hline Mean \pm standard deviation & $81.3 \pm 21.4$ & $80.7 \pm 22.3$ & \\
\hline DLCO $(\%$ predicted $)$ & & & .63 \\
\hline Mean \pm standard deviation & $73.5 \pm 22.4$ & $74.0 \pm 22.3$ & \\
\hline Year of surgery $(\%)$ & & & .97 \\
\hline $2001-2004$ & 2.7 & 2.4 & \\
\hline 2005 & 3.8 & 3.4 & \\
\hline 2006 & 7.9 & 8.1 & \\
\hline 2007 & 11.8 & 12.1 & \\
\hline 2008 & 16.7 & 16.4 & \\
\hline 2009 & 38.4 & 38.2 & \\
\hline 2010 & 18.7 & 19.4 & \\
\hline Clinical status (\%) & & & .74 \\
\hline Elective & 98.1 & 97.9 & \\
\hline Urgent & 0.7 & 0.8 & \\
\hline Emergent & 1.2 & 1.3 & \\
\hline $\begin{array}{l}\text { General thoracic } \\
\text { reoperation }(\%)\end{array}$ & & & .27 \\
\hline Yes & 3.8 & 3.2 & \\
\hline Prior thoracic surgery $(\%)$ & & & .71 \\
\hline Yes & 12.3 & 12.0 & \\
\hline Laterality of procedure $(\%)$ & & & .76 \\
\hline Right & 58.6 & 59.0 & \\
\hline $\begin{array}{l}\text { American Society of } \\
\text { Anesthesiologists risk } \\
\text { class }(\%)\end{array}$ & & & .98 \\
\hline I-II & 18.7 & 18.8 & \\
\hline III & 74.3 & 74.1 & \\
\hline IV-IV & 7.0 & 7.1 & \\
\hline Cigarette smoker $(\%)$ & & & .49 \\
\hline Never & 14.4 & 13.7 & \\
\hline Ever & 85.6 & 86.3 & \\
\hline
\end{tabular}

TABLE 3. Continued

\begin{tabular}{|c|c|c|c|}
\hline & $\begin{array}{l}\text { Thoracotomy } \\
(\mathrm{n}=\mathbf{2 7 4 5 )}\end{array}$ & $\begin{array}{c}\text { Video-assisted } \\
\text { thoracic } \\
\text { surgery } \\
(n=2745)\end{array}$ & $\begin{array}{c}P \\
\text { value }\end{array}$ \\
\hline Zubrod score & & & .45 \\
\hline 0 & 46.9 & 47.2 & \\
\hline 1 & 48.2 & 47.8 & \\
\hline 2 & 3.9 & 4.3 & \\
\hline 3 & .8 & .7 & \\
\hline 4 & .1 & 0 & \\
\hline $\begin{array}{l}\text { Weight loss } 3 \text { mo before } \\
\text { admission }(\mathrm{kg})\end{array}$ & & & .90 \\
\hline Mean \pm standard deviation & $0.6 \pm 3.0$ & $0.7 \pm 3.6$ & \\
\hline Hypertension (\% yes) & 66.3 & 66 & .80 \\
\hline Steroid use ( $\%$ yes) & 3.7 & 3.6 & .83 \\
\hline $\begin{array}{l}\text { Congestive heart failure } \\
\text { ( } \% \text { yes })\end{array}$ & 3.5 & 2.9 & .25 \\
\hline $\begin{array}{l}\text { Coronary artery disease } \\
\text { ( } \% \text { yes) }\end{array}$ & 22.7 & 22.7 & .97 \\
\hline $\begin{array}{l}\text { Peripheral vascular disease } \\
\text { ( } \% \text { yes })\end{array}$ & 10.7 & 11.1 & .63 \\
\hline Renal insufficiency ( $\%$ yes) & 2.9 & 2.5 & .35 \\
\hline
\end{tabular}

FEV1, Forced expiratory volume in 1 second; $D L C O$, carbon monoxide diffusing capacity. *Estimated surgeon volume was calculated by dividing the number of study cases $(11,531$ lobectomies and segmentectomies) performed by the surgeon over the time frame in which the surgeon submitted cases.

lung cancer was resected by VATS. This finding echoes a previous STS database study, but is contrary to other large institutional series. ${ }^{13}$ The implications of this reduction in atrial fibrillation are considerable, because the effect of perioperative atrial fibrillation on a patient's quality of life and overall health care expenditures is significant and extends beyond hospitalization. ${ }^{14}$

Readmissions in our study were similar to rates recently reported for lung cancer surgery. ${ }^{15}$ It is unclear why the readmissions did not differ by approach, but likely reflects a lack of difference in the types of complications that lead to readmission.

We explored the possibility that the lower complication rates in the VATS cohort were secondary to greater surgical experience among the surgeons performing VATS procedures. We did in fact find that the VATS procedures were done by surgeons with a greater annual volume (median, 20.4 cases per year for VATS vs 15.7 cases for thoracotomy). However, a multivariable analysis demonstrated that the effect of approach (VATS having fewer complications) remained significant when adjusting for differences in volume. Therefore, the thoracotomy approach appears to be an independent risk factor for complications in patients with clinical stage I cancer.

It was not possible to determine which patients were converted from VATS to thoracotomy, which has the potential to bias against the outcomes of the thoracotomy group. Although it is encouraging that complication rates 
TABLE 4. Complications by surgical approach in propensity-matched cases

\begin{tabular}{|c|c|c|c|}
\hline & $\begin{array}{l}\text { Thoracotomy } \\
(n=2745)\end{array}$ & $\begin{array}{c}\text { Video-assisted } \\
\text { thoracic } \\
\text { surgery } \\
(n=2745)\end{array}$ & $\begin{array}{c}P \\
\text { value }\end{array}$ \\
\hline Operative times (min) & & & $<.001$ \\
\hline $\begin{array}{l}\text { Median (interquartile } \\
\text { range) }\end{array}$ & $145(109-196)$ & $173(128-220)$ & \\
\hline Length of stay (median d) & 5 & 4 & $<.001$ \\
\hline Interquartile range & $(4-8)$ & $(3-6)$ & \\
\hline Length of stay $>14 \mathrm{~d}^{*}(\%)$ & 7.4 & 4.3 & $<.001$ \\
\hline $\begin{array}{l}\text { Operative mortality (hospital } \\
\text { or } 30-\mathrm{d})(\%)\end{array}$ & 1.8 & 1.3 & .12 \\
\hline $\begin{array}{l}\text { Readmission within } 30 \mathrm{~d} \text { of } \\
\text { surgery }(\%) \dagger\end{array}$ & 5.5 & 6.2 & .42 \\
\hline Any complication (\%) & 36.2 & 29.9 & $<.001$ \\
\hline $\begin{array}{l}\text { Any pulmonary } \\
\text { complication }(\%)\end{array}$ & 20.8 & 18.3 & .017 \\
\hline Air leak $>5 \mathrm{~d}$ postoperation & 10.9 & 10.7 & .90 \\
\hline $\begin{array}{l}\text { Patient discharged with } \\
\text { chest tube }\end{array}$ & 5.9 & 8.4 & $<.001$ \\
\hline $\begin{array}{l}\text { Atelectasis requiring } \\
\text { bronchoscopy }\end{array}$ & 4.1 & 2.7 & .005 \\
\hline Pneumonia & 4.6 & 3.4 & .033 \\
\hline Adult respiratory distress & 1.1 & 0.5 & .006 \\
\hline Bronchopleural fistula & 0.3 & 0.3 & 1 \\
\hline Pulmonary embolus & 0.4 & 0.3 & .51 \\
\hline Initial vent support $>48 \mathrm{~h}$ & 0.8 & 0.4 & .076 \\
\hline Reintubation & 4.3 & 2.8 & .003 \\
\hline Tracheostomy & 1.2 & 1 & .51 \\
\hline $\begin{array}{l}\text { Any cardiovascular } \\
\text { complication }(\%)\end{array}$ & 15 & 11.3 & $<.001$ \\
\hline $\begin{array}{l}\text { Atrial arrhythmia requiring } \\
\text { treatment }\end{array}$ & 12.7 & 9.7 & $<.001$ \\
\hline $\begin{array}{l}\text { Ventricular arrhythmia } \\
\text { requiring treatment }\end{array}$ & 0.9 & 0.5 & .057 \\
\hline Myocardial infarction & 0.3 & .2 & .44 \\
\hline $\begin{array}{l}\text { Deep vein thrombosis } \\
\text { requiring treatment }\end{array}$ & 0.5 & 0.4 & .84 \\
\hline $\begin{array}{l}\text { Any hematology } \\
\text { complication (\%) }\end{array}$ & 8.6 & 5.4 & $<.001$ \\
\hline $\begin{array}{l}\text { Bleeding requiring } \\
\text { reoperation }\end{array}$ & 1.1 & 1.3 & .46 \\
\hline $\begin{array}{l}\text { Blood transfusion } \\
\text { intraoperatively }\end{array}$ & 2.8 & 1.1 & $<.001$ \\
\hline $\begin{array}{r}\text { Blood transfusion } \\
\text { postoperatively }\end{array}$ & 6.2 & 4 & $<.001$ \\
\hline $\begin{array}{l}\text { Any infectious } \\
\text { complication }(\%)\end{array}$ & 3.6 & 3 & .17 \\
\hline Urinary tract infection & 2.1 & 2 & .70 \\
\hline $\begin{array}{l}\text { Empyema requiring } \\
\text { treatment }\end{array}$ & 0.6 & 0.3 & .041 \\
\hline Wound infection & 0.4 & 0.4 & .83 \\
\hline Sepsis & 0.9 & 0.4 & .013 \\
\hline $\begin{array}{l}\text { Any neurologic } \\
\text { complication }(\%)\end{array}$ & 3.7 & 2.3 & .003 \\
\hline
\end{tabular}

TABLE 4. Continued

\begin{tabular}{|c|c|c|c|}
\hline & $\begin{array}{l}\text { Thoracotomy } \\
(n=2745)\end{array}$ & $\begin{array}{c}\text { Video-assisted } \\
\text { thoracic } \\
\text { surgery } \\
(n=2745)\end{array}$ & $\begin{array}{c}P \\
\text { value }\end{array}$ \\
\hline New central neurologic event & 0.7 & 0.4 & .19 \\
\hline $\begin{array}{l}\text { Recurrent laryngeal nerve } \\
\text { paresis }\end{array}$ & 0.3 & 0.1 & .058 \\
\hline Delirium & 2 & 1.3 & .045 \\
\hline $\begin{array}{l}\text { New renal failure or creatinine } \\
\geq 2 \times \text { preoperative }(\%)\end{array}$ & 2 & 1.1 & .006 \\
\hline
\end{tabular}

remained lower in the VATS cohort despite the exclusion of cases with multiple approaches listed, without a specific conversion data field it is not possible to distinguish conversions from true diagnostic procedures before a planned thoracotomy.

\section{Limitations}

The principle limitations include a potential for selection bias for cases submitted to the database, because participation is voluntary. In addition, it is possible that patients undergoing VATS were healthier in ways not captured by the database. The database cannot distinguish conversions from VATS to thoracotomy; therefore, these particularly challenging cases would be coded in the thoracotomy group. The differences in atrial fibrillation prevalence and other complications may reflect other aspects of perioperative management unrelated to surgical approach (such as use of perioperative beta blockers or improved pulmonary toilet). We attempted to exclude surgeon volume as a confounder of the approach effects. The effect of approach on complications remained independent of volume effects in multivariable analysis. However, we only considered volume within the case series (11,531 clinical stage I lobectomies and segmentectomies), and therefore we may have underestimated the surgical experience of surgeons who perform significant numbers of resections for more advanced primary lung cancer (clinical stage II or III) or benign disease. We also did not separate surgeon case volume into VATS from thoracotomy annual experience, recognizing the possibility that the importance of approach-specific experience may be missed.

\section{CONCLUSIONS}

Postoperative complications are less common following anatomic resection of clinical stage I lung cancer performed by Board-certified thoracic surgeons using the VATS approach instead of thoracotomy. This should be taken into consideration when counseling patients for surgery. 
TABLE 5. Comparison of complications by approach for lobectomy or segmentectomy for lung cancer in the literature

\begin{tabular}{|c|c|c|c|c|}
\hline Database & Total complications & Thoracotomy & $\begin{array}{l}\text { Video-assisted } \\
\text { thoracic surgery }\end{array}$ & $\begin{array}{c}P \\
\text { value* }\end{array}$ \\
\hline Healthcare Utilization Project-National Inpatient Sample ${ }^{10}$ & $2657 / 6292(42.2)$ & $2074 / 4769(43.5)$ & $583 / 1523(38.3)$ & $<.001$ \\
\hline American College of Surgeons National Surgical Quality Improvement Program ${ }^{9}$ & $496 / 2353(21.1) \dagger$ & $412 / 1737(23.7) \dagger$ & $84 / 616(13.6) \dagger$ & $<.001$ \\
\hline Surveillance, Epidemiology, and End Results ${ }^{8}$ & 2329/4171 (55.8) & NA & NA & NA \\
\hline Society of Thoracic Surgeons previous report - all stagesł,$^{3}$ & $780 / 2562(30.4)$ & $444 / 1281(34.7)$ & $336 / 1281(26.2)$ & $<.001$ \\
\hline Society of Thoracic Surgeons current report - clinical stage $I \ddagger$ & $1816 / 5490(33.1)$ & $994 / 2745(36.2)$ & $822 / 2745$ (29.9) & $<.001$ \\
\hline
\end{tabular}

Data are presented as $\mathrm{n}(\%) . N A$, Not available. *Between thoracotomy and video-assisted thoracic surgery. †Atrial fibrillation not included. $\ddagger$ Propensity-matched cohorts.

\section{References}

1. Aberle D, Adams AM, Berg CD, Black WC, Clapp JD, et al. Reduced lung-cancer mortality with low-dose computed tomographic screening. $N$ Engl J Med. 2011;365:395-409.

2. Ginsberg RJ, Rubinstein LV. Randomized trial of lobectomy versus limited resection for T1 N0 non-small cell lung cancer. Lung Cancer Study Group. Ann Thorac Surg. 1995;60:615-22.

3. Paul S, Altorki NK, Sheng S, Lee PC, Harpole DH, Onaitis MW, et al. Thoracoscopic lobectomy is associated with lower morbidity than open lobectomy: a propensity-matched analysis from the STS database. J Thorac Cardiovasc Surg. 2010;139:366-78.

4. Demmy TL, Nwogu C. Is Video-Assisted Thoracic Surgery Lobectomy Better? Quality of Life Considerations. Ann Thorac Surg. 2008;85:S719-28.

5. Boffa DJ, Kosinski AS, Paul S, Mitchell JD, Onaitis M. Lymph node evaluation by open or video-assisted approaches in 11,500 anatomic lung cancer resections. Ann Thorac Surg. 2012;94:347-53.

6. Parson L. Reducing bias in a propensity score matched-pair sample using greedy matching techniques. In: Proceedings of the twenty-sixth Annual SAS Users Group International Conference. Long Beach: SAS Inc; 2001 .

7. Gopaldas RR, Bakaeen FG, Dao TK, Walsh GL, Swisher SG, Chu D. Video-assisted thoracoscopic versus open thoracotomy lobectomy in a cohort of 13,619 patients. Annals Thorac Surg. 2011;89:1563-70.

8. Farjah F, Wood DE, Mulligan MS, Krishadasan B, Heagerty PJ, Symons RG, et al. Safety and efficacy of video-assisted versus conventional lung resection for lung cancer. J Thorac Cardiovasc Surg. $2009 ; 137: 1415-21$
9. Phillips JD, Merkow RP, Sherman KL, DeCamp MM, Bentrem DJ, Billimoria KY. Factors affecting selection of operative approach and subsequent short-term outcomes after anatomic resection for lung cancer. J Am Coll Surg. 2012;215:206-15.

10. Park HS, Detterbeck FC, Boffa DJ, Kim AW. Impact of hospital volume of thoracoscopic lobectomy on primary lung cancer outcomes. Annals Thorac Surg. 2012;93:372-9.

11. Ceppa DP, Kosinski AS, Berry MF, Tong BC, Harpole DH, Mitchell JD, et al. Thoracoscopic lobectomy has increasing benefit in patients with poor pulmonary function: a Society of Thoracic Surgeons database analysis. Ann Surg. 2012;256:487-93.

12. Balsara KR, Balderson SS, D'Amico TA. Surgical techniques to avoid parenchymal injury during lung resection (fissureless lobectomy). Thorac Surg Clin. 2010;20:365-9.

13. Park BJ, Zhang H, Rusch VW, Amar D. Video-assisted thoracic surgery does not reduce the incidence of postoperative atrial fibrillation after pulmonary lobectomy. J Thorac Cardiovasc Surg. 2007;133:775-9.

14. Mahoney EM, Thompson TD, Veledar E, Williams J, Weintraub WS. Cost effectiveness of targeting patients undergoing cardiac surgery for therapy with intravenous amiodarone to prevent atrial fibrillation. J Am Coll Cardiol. 2002; 40:737-45.

15. Freeman RK, Dilts JR, Ascioti AJ, Dake M, Mahidhara RS. A comparison of length of stay, readmission rate, and facility reimbursement after lobectomy of the lung. Ann Thorac Surg. 2013;96:1740-6.

16. Wright CD, Galssert HA, Grab JD, O'Brien SM, Peterson ED, Alen MS. Predic tors of prolonged length of stay after lobectomy for lung cancer: a Society of Thoracic Surgeons General Thoracic Surgery Database risk-adjustment model Ann Thorac Surg. 2008;85:1857-65. 